\title{
Perceptions of Spanish nurses on economic crisis and the impacts on health care system
}

\author{
Percepções de enfermeiras espanholas sobre a crise econômica e os impactos no sistema de saúde
}

Percepciones de enfermeras españolas acerca de la crisis económica y sus impactos en el sistema sanitario

\section{Helena Maria Scherlowski Leal David' ORCID: 0000-0001-8002-6830 \\ José Ramón Martínez-Riera" ORCID: 0000-0002-4926-6622 \\ Sonia Acioli' ORCID: 0000-0002-0772-8235 \\ Maria Fernanda de Lima da Costa"' ORCID: 0000-0002-1077-1381}

'Universidade do Estado do Rio de Janeiro. Rio de Janeiro, Rio de Janeiro, Brazil.

"Universidad de Alicante. Alicante, Comunidade Valenciana, Espanha.

I' Hospital Geral de Málaga. Málaga, Andaluzia, Espanha.

How to cite this article:

David HMS, Martínez-Riera JR, Acioli S, Costa MFL. Perceptions of Spanish Nurses on economic crisis and the impacts on health care system.

Rev Bras Enferm. 2020;73(3):e20190283. doi: http://dx.doi.org/10.1590/0034-7167-2019-0283

Corresponding author: Helena Maria Scherlowski Leal David E-mail: helenalealdavid@gmail.com

EDITOR IN CHIEF: Dulce Aparecida Barbosa ASSOCIATE EDITOR: Hugo Fernandes

Submission: 03-29-2019

Approval: 10-06-2019
ABSTRACT
Objective: to analyze the perceptions of Spanish nurses regarding the country's economic
crisis situation, and its impacts on nursing work, health system and population's health.
Methods: qualitative approach, with data collection using an internet-based questionnaire
and individual in-depth interviews. Data were analyzed according to Thematic-Categorical
Content Analysis, supported by Historical and Dialectical Materialism perspective. Results:
the categories produced discuss themes as: cutbacks in health care and the consequences of
workforce non-replacement and work overload; salary impact; care model changes; negative
impacts on population health. The impact on population health and work was discussed,
especially regarding vulnerable groups, as well as in assistance model reconfiguration,
reinforcing the biomedical and assistance perspective. Final considerations: the perspective
of Spanish nursing points to the increase of liberal policies and their expression in health
sector, and to the role of nursing in universal health care systems.
Descriptors: Nurses; Primary Health Care; Community Health Services; Economics; Impacts Descriptors
on Health.

\section{RESUMO}

Objetivo: analisar as perceções de enfermeiras espanholas quanto à conjuntura de crise econômica e seus impactos no trabalho, no sistema de saúde e na saúde da população. Método: abordagem qualitativa; coleta de dados por questionário publicado na internet e em entrevistas individuais. Análise com base na Análise de Conteúdo Temático-Categorial, apoiada pela perspectiva teórica do materialismo histórico-dialético. Resultados: as categorias produzidas abordam temas como: cortes financeiros e seus impactos de não reposição da força de trabalho, sobrecarga de trabalho, impacto salarial e na oferta de emprego; ênfase em um modelo de saúde biomédico; impactos negativos na saúde da população. Discussão: destacam-se impactos no trabalho e na saúde, sobretudo nos grupos vulneráveis, assim como sobre o modelo assistencial reforçando a perspectiva biomédica. Considerações finais: as percepções da enfermagem espanhola apontam para o acirramento das políticas liberais e sua expressão na saúde e para o papel da enfermagem nos sistemas de saúde.

Descritores: Enfermeiras e Enfermeiros; Atenção Primária à Saúde; Serviços de Saúde Comunitária; Economia; Impactos na Saúde.

\section{RESUMEN}

Objetivo: analizar las percepciones de las enfermeras españolas en cuanto a la coyuntura de crisis económica vivenciada por el país y sus impactos en el trabajo, en el sistema de salud y en la salud de la población. Métodos: enfoque cualitativo, con recolección de datos por medio de un cuestionario publicado en Internet y a partir de entrevistas individuales en profundidad. Los datos fueron analizados con base en el Análisis de Contenido Temático-Categorial, con suporte teórico del Materialismo Histórico y Dialético. Resultados: las categorías discuten temas como: los cortes financieros y sus impactos de no-reposición de la fuerza de trabajo, sobrecarga de trabajo, impacto salarial y en las plazas de trabajo; énfasis en un modelo asistencial biomedico; impactos negativos en la salud de la población. Se discutieron los impactos en el trabajo y la salud de la población, sobre todo en los grupos vulnerables, así como en la reconfiguración del modelo asistencial, reforzando la perspectiva biomédica y asistencial. Consideraciones finales: la perspectiva de la enfermería española apunta hacia el agravamiento de las políticas liberales y su expresión en la salud, y para el papel de la enfermería en los sistemas universales de salud. Descriptores: Enfermeras y Enfermeros; Atención Primaria de Salud; Servicios de Atención Comunitaria; Economía; Impactos en la Salud. 


\section{INTRODUCTION}

Primary Health Care (PHC) is one of the historical milestones of the western civilizing process. From the second half of the twentieth century, is considered one of the main technological innovations of health. PHC proposed epistemological and conceptual transformations, and changed strategies and practices of health work ${ }^{(1)}$. It is mainly from the propositions derived from the Alma-Ata Declaration of 1978 that $\mathrm{PHC}$ is reconfigured as a preferential strategy for access to health care based on the concepts of universality and comprehensiveness. PHC is an inseparable public policy of the economic and social development of countries. From then on, the directions that $\mathrm{PHC}$ took in each country were contingent on the complex interaction of factors such as historical development path, economic and political bases and state-society relationship, among others. It is important to note that this was not a path free of tensions and setbacks, with the production of contradictions, especially between the characteristics of universal care and the perspectives of focus and selectivity.

Western countries, especially European countries, have adopted universal system models strongly supported by problem-solving $\mathrm{PHC}$ focused on the main health problems of the population and with a central role of the general practitioner ${ }^{(2)}$. Nursing has been integrating these systems in several ways, with important differences regarding the levels of professional education. Thus, the ways in which nursing integrates the level of $\mathrm{PHC}$ has also been different in different countries.

Nurses are internationally essential professionals for PHC access. In their performance, the capacity of intervention for health promotion, the development of health education practices, the community participation and the comprehensive care for individuals, families and communities stand out ${ }^{(3)}$. $\mathrm{PHC}$ is a predominantly state field of action. The presence of nurses in all types of units and services demonstrates a historical commitment and shared professional values around the world ${ }^{(4)}$.

Spain, after overcoming through a strong welfare system the regional inequalities and poverty resulting from the post-Civil War years and under the Franco regime, has been going through a remarkable process of social development since the 1970s. economic. This process resulted in one of the highest life expectancies in Europe, surpassing the world average. The current population's health profile is marked by a high prevalence of Noncommunicable Chronic Diseases associated with aging profile and other factors. As part of the country's development process, from the 1980s onwards, there was a significant investment in $\mathrm{PHC}$ as the preferred gateway, with other services and levels encompassed under the heading of Specialized Care ${ }^{(5)}$. There is no provision of $\mathrm{PHC}$ services by the private sector, despite the lack in the service portfolio of some specialized procedures such as orthodontics and ophthalmology services.

This economic development had been consolidating around industrial production and real estate market expansion, suffering a deep thump from 2008, when the crisis of the North American economic markets hit Europe. This crisis caused a recession to a greater or lesser extent in all countries. This is a crisis situation within an economic structure of neoliberal capitalism. It has its origins decades earlier in the induced changes in the economy, which increasingly rely on a model of financial capital expansion.
This model is based on household indebtedness, mainly through housing financing(6). In the correlation of forces between the working class and capital, European states mediation eventually capitulated to central countries demands of the European Union. This has also occurred as workers continue to seek to organize to resist and demand social welfare policies.

The way in which European countries responded to bank failures has led to cutbacks in public resources, including public health and education policies, through the so-called austerity measures imposed by troika. In Spain this has resulted in severe restrictions on health policy establishment in all Autonomous Communities, although not in the same way ${ }^{(7)}$.

The main problems attributed to the Spanish crisis include: rapid and significant increase in unemployment, with greater penalties in sectors such as construction; stagnation of real estate growth; financial capacity of the indebted population to repay mortgages, resulting in a large number of real estate evictions in the country; worsening living conditions of vulnerable groups through loss of purchasing power, with impacts in terms of changes and dietary restrictions; difficulty for low-income residents and migrants to access health care and purchase medicines; increased prevalence of mental problems including an increase in localized suicide rate in some specific groups and regions ${ }^{(7-8)}$.

From the point of view of work in health and nursing, job vacancies supply has shrunk, meanwhile workforce replacement has been interrupted. Alternative and precarious forms of hiring have become more widely used such as temporary and shortterm contracts. Among Spanish nurses, there has also been an increase in the number of migrations to other countries as a way of seeking better remuneration and access to social welfare policies $^{(9)}$. It is considered that Spain is still in crisis, as the pace of economic growth has not resumed at previous levels, although the severity of the situation is now lessened.

We start from the assumption that PHC nurses are strategic social actors for the health sector to cope with the consequences of crises that affect social policies. Their professional practice, however, is not immune to the consequences of the crisis regarding the profile of population health, especially of vulnerable groups, and to changes that are ultimately imposed on the health work world.

Over the past five or six years, Brazil has been progressively suffering the late effects of this crisis, coupled with a serious political and institutional crisis and the establishment of reformist austerity measures. These measures have real and potential ability to negatively impact health sector policy. As an example, there are two recent measures: Parliamentary Amendment Proposal 241 adoption, the so-called "spending ceiling" (or "Death") PEC (Proposta de Emenda Constitucional - Proposed Constitutional Amendment) in 2016. This proposal limits public spending for the next 20 years. And labor sector reform, with measures of flexibility and deregulation of labor relations, approved by the Brazilian National Congress in $2017^{(10)}$.

Knowing how Spanish nurses perceive this long duration crisis situation and what the consequences for their work and population health can contribute to make visible the effects of economic crises on the daily work of PHC. It will also make visible the role of nursing, with a view to ensuring comprehensive and universal care, even in unfavorable situations. As already pointed out, international studies in comparative perspective 
on nursing work in PHC constitute a little explored research field. Also in relation to which important aspects to be discussed at the international level seem to converge, such as the role of nursing in the performance of universal health systems.

\section{OBJECTIVE}

To analyze the perceptions of Spanish nurses regarding the country's economic crisis situation, and its impacts on nursing work, health system and population health.

\section{METHOD}

\section{Ethical aspects}

The study was submitted and approved by the Research Ethics Committees of Universidade Estadual do Rio de Janeiro (CAAE (Certificado de Apresentação para Apreciação Ética - Certificate of Presentation for Ethical Consideration) 95196018.4.1001.5282) and Universidad de Alicante, Spain (Expedient UA-2018-09-14). The article structure spells out the methodological steps based on the Consolidated Criteria for Reporting Qualitative Research (COREQ).

\section{Theoretical-methodological framework}

The research design is qualitative and supported by the theoretical perspective of historical-dialectical materialism, considering micro and macro structural aspects in phenomena production and social life work centrality ${ }^{(11)}$. The methodological procedures were mixed: i) publication of a survey questionnaire to be answered on the internet, open to nurses working in PHC and ii) in-depth individual interviews with nurses from three Spanish Autonomous Communities.

\section{Methodological procedures}

Questionnaire preparation and testing was performed by the first author, validating the tool through testing with five native Spanish nurses. The questionnaire character includes descriptive quantitative variables for purposes of participant characterization. There was no statistical validation indication. Respondents were given access to a description of the study objectives and the Free and Informed Consent Term before starting to respond. They have the option to accept or withdraw from the site. The questionnaire consisted of three sections: i) sociodemographic data (formation, family data, place of birth, and housing); ii) PHC work data (motivations, forms of entry and working time in PHC); iii) respondents' perception of the impacts of the crisis on their work, nursing work, the population's profile served and the future of the crisis situation. The survey included open, non-mandatory questions requesting more detailed explanations to be recorded in non-space limited fields. The questionnaire was opened for responses in mid-February 2019. The responses analyzed refer to 62 responses obtained by the end of March 2019. One respondent chose not to continue filling in, which was allowed at any time. These are partial results as the questionnaire will remain open for answers.

\section{Study setting}

Individual interviews were conducted face to face or by telephone. Seven nurses from three Autonomous Communities participated (Valencian Community (4 respondents), Andalusian Community (2 respondents) and Basque Country (one respondent)). Speeches are identified with the Community's acronym, followed by number (VC 1, VC 2,VC 3 and VC; A1 and A2; BC). Participants were selected through the snowballing method, based on referrals from researchers and PHC nurses. Interviews lasted, on average, 45 minutes. They were recorded on a mobile device and conducted by the lead author and the third author after explanation of the study objectives and signing of the Free and Informed Consent Term. The script was semi-open, containing three main questions: how do you perceive the effects of the crisis on your work and on the work of PHC nursing? How do you perceive the effects of the crisis on the population's health? How do you see the future of the country and PHC?

\section{Collection and organization of data}

Questionnaire's open answers' contents was transcribed and organized into tables for reading and subsequent identification of thematic nuclei. Individual interviews' contents were fully transcribed and resent to the interviewees for validation and eventual correction. The number of participants in this stage considered criteria of data saturation and recurrence of thematic elements.

\section{Data analysis}

Systematization was based on the steps of Categorical Thematic Content Analysis. There was text skimming and intuitive reading, identification of thematic nuclei, such as record units (RU) and aggregation of them into thematic categories or themes, derived from the data ${ }^{(12)}$. The themes were selected from RU frequency criteria. Discursive elements such as concrete situations, names of people or localities were omitted from the final systematization.

The thematic categories identified in the survey responses were: cutbacks in PHC; workforce non-replacement and work overload; salary impact; care model changes; negative impacts on population health.

The themes derived from the analysis of the interviews were the same, and allowed to deepen the analysis around the causes and consequences of the crisis for nurses, population and health system.

\section{RESULTS}

\section{Internet survey results}

The profile of nurses who answered the questionnaire consisted of people with an average age of 45 years that ranged from 23 to 62 years. Mostly graduated from public institutions $(95.7 \%)$, and were working in PHC on average 16 years ago (0-39). They reported living in 19 Autonomous Communities in the country. Distribution by sex was $86 \%$ women and $14 \%$ men.

The most frequently reported type of employment contract was the public sector fixed contract (plaza en propiedad), with $56.1 \%$ of responses. Interim contracts (temporary hiring to replace 
vacancy for vacations or leave, with fixed time) were informed, with $22.8 \%$, and eventual (type of contract of very short duration, may be for days or even hours), with 17,5\%.

The vast majority (89.5\%) work full-time, i.e., 35 hours per week, usually divided into 7 hours per day. They occupy positions as nurses referring to $\mathrm{PHC}(73.7 \%)$, or coordinating/managing (17.6\%). Position entry can take place by contest, with vacancies open only within the Autonomous Community, denominated by opposition (56.1\%), by transfer from another health center (24.6\%) or by transfer from the hospital (19.3\%). For $40.4 \%$ of respondents working as a nurse in PHC is the only source of family income. Salary ranged from less than 1,500 euros (14.0\%), from 1,501 to 2,500 euros (73.7\%), and more than 2,501 euros (12.3\%).

When asked if the crisis affected their own work, 50.9\% reported that it affected a lot; $36.8 \%$ answered that it affected them in some way; the others reported that it affected little, nothing or could not say.

This question was followed by another open-ended question asking for an explanation of the previous answer. Among those who considered that the crisis affected much or somehow their own work, the explanations, organized as themes, can be seen in Chart 1. The first column also brings the terms used, in the second column the explanatory description of each and in the third column, the number of answers that mentioned the themes. The total number of nurses who answered was 48 (77.4\%). One respondent reported that he was not yet working in the crisis period, and the others left the answer blank. The theme count exceeds the number of respondents, as some nurses mentioned more than one theme in their response.

About the impacts of the crisis on the population's health that are attended at health centers, the nurses mentioned several conditions that arose such as mental problems. Other problems have also been aggravated, especially among the most vulnerable groups: migrants, gypsies, elderly, out-of-income, dependent on reduced pensions or social assistance. Issues and problems described are systematized in Chart 2, without organization by frequency of answers or number of respondents.

\section{Individual interviews results}

Respondents describe the effects of the crisis in broad, related and complex terms, affecting the various economic sectors and aggravated by austerity measures and consequent resource cutbacks:

When the economic and financial crisis comes, causing all this and housing prices rose in a scandalous way. That is to say that there was a lot, a lot of offer, but also a very expensive offer, but since they were cheap for people, they got mortgaged, going, for 25 and 50 years to pay for the house... when the crack occurs, because of the financial and economic crisis and people can't pay, they can't cope with that because massive layoffs begin, construction is paralyzed. It is paralyzed, it goes from a massive construction to a standstill, then all these people who had been working on the construction are unemployed, and everything that the construction carried, dragged. Therefore, all companies related to construction, with construction materials - steels, marbles, everything. It goes in chain and falling, with which they begin to increase the number of unemployed in Spain, the first evictions begin to appear... (VC 2)
Chart 1 - Themes from the answers to the question: Do you think the crisis has affected your work?

\begin{tabular}{|c|c|c|}
\hline Theme & Description & $\mathbf{N}$ \\
\hline $\begin{array}{l}\text { Cutbacks in health and } \\
\text { PHC policies } \\
\text { (cutbacks in health, } \\
\text { cutbacks have affected the } \\
\text { health system, cutbacks in } \\
\text { inversion and in material } \\
\text { and human resources, } \\
\text { investigation of inversion } \\
\text { in PHC) }\end{array}$ & $\begin{array}{l}\text { During the crisis, there were } \\
\text { adjustments and cutbacks in the } \\
\text { health sector of all Autonomous } \\
\text { Communities. This resulted in a halt to } \\
\text { PHC expansion or improvement, with } \\
\text { some decrease in material resources } \\
\text { (equipment, inputs) and stagnation in } \\
\text { the number of jobs, with an increase } \\
\text { in the waiting list for vacancies. }\end{array}$ & 24 \\
\hline $\begin{array}{l}\text { Workforce non- } \\
\text { replacement of and work } \\
\text { overload (lack of support } \\
\text { and contract, meager } \\
\text { support, accumulation of } \\
\text { work, overload of work, } \\
\text { bad work) }\end{array}$ & $\begin{array}{l}\text { There was no replacement of workers' } \\
\text { vacancies resulting from vacations, } \\
\text { leave or retirement, which should } \\
\text { automatically generate vacancies by } \\
\text { temporary contracts. Accumulation } \\
\text { of tasks and work overload were the } \\
\text { consequences mentioned. }\end{array}$ & 21 \\
\hline $\begin{array}{l}\text { Salary impact } \\
\text { (salary reduction and } \\
\text { paralysis in the payment } \\
\text { of overtime) }\end{array}$ & $\begin{array}{l}\text { It was mentioned that there was a } \\
\text { decrease in salary, but what can be } \\
\text { verified is that overtime pay was } \\
\text { suspended, impacting the salaries of } \\
\text { those who had this additional. }\end{array}$ & 14 \\
\hline $\begin{array}{l}\text { PHC care practice changes } \\
\text { (resources for PHC will be } \\
\text { cut, policies have gone } \\
\text { due to the health system, } \\
\text { especially PHC, PHC has } \\
\text { poor skills, poor health } \\
\text { care, if curative care is } \\
\text { poor) }\end{array}$ & $\begin{array}{l}\text { There were changes in management } \\
\text { and organization of work in PHC } \\
\text { resulted in the introduction of } \\
\text { procedures that were previously } \\
\text { performed by Specialized Care. } \\
\text { Coupled with work overload and } \\
\text { shrinking jobs, it has resulted in } \\
\text { worsening quality of care and } \\
\text { difficulty in health promotion and } \\
\text { prevention, with a greater focus on } \\
\text { curative actions. }\end{array}$ & 07 \\
\hline $\begin{array}{l}\text { Negative impacts on } \\
\text { population health } \\
\text { (need for settlement, } \\
\text { could not buy drugs } \\
\text { and food, patients in } \\
\text { economic and labor } \\
\text { precarious situation, type } \\
\text { of pathologies) }\end{array}$ & $\begin{array}{l}\text { Among the most vulnerable } \\
\text { population groups, unemployment } \\
\text { and loss of purchasing power were } \\
\text { more intense. Type of food had } \\
\text { to change. Subsidies they had for } \\
\text { the purchase of medicines were } \\
\text { reduced or withdrawn. }\end{array}$ & 05 \\
\hline
\end{tabular}

The crisis hits everyone, but not in the same way. The consequences in terms of impacts on population health are presented considering variables of ethnicity, sex, age, and socioeconomic capacity, especially the situation of having or not having a job:

Well, the crisis has caused chronic diseases to increase. Why? Because for example, here in this population, here everything that is food, exercise, what are healthy habits, because I see it wrong... for example, I have chronic diabetic patients, who tell me, yes it is very good that I have to take some advice, but, or I pay the light, or I do the diet. It is that we are seven in the family, all unemployed, we live with 400 euros of the grandmother's pension, with two children, an oncological patient, and the older person, who is the one with 400 euros, has hypoglycemia. But he eats once a day for children to eat two. The crisis affects this population more...children are in school, most school children to eat at school every day. (VC 1)

What nobody can deny is that it increased significantly in the poverty thresholds in Spain. That is to say, there were more and 
Chart 2 - Conditions or problems of the population served by nurses during the crisis

Cutbacks in the Dependency Law increases the morbidity and mortality of the elderly: fractures, ulcers, income complications...Disappearance of home help teams for terminally ill patients. Nutrition problems with children...

Patients who do not have money to pay for pharmacological treatment or even not have money to go to a gym.

Functional/cognitive worsening of elderly patients immobilized due to delay in the processing of socio-health resources

Mental problems, anxiety, depression...

There were situations in the psychosocial and emotional area due to lack of employment. Also in some cases problems to buy some drugs. In smaller order, serious problems for the basic purchase of food and other products. I have patients who need to go to the local food bank.

The purchasing level of some patients worsened and they could not access medical treatments because of the pharmaceutical co-participation.

Late diagnostic exams, late visits.

Some patients do not follow the treatment because they cannot afford it.

The economic problems of the population have resulted in social/health problems.

Concern, stress.

People over 50 years of age who lost their jobs and were unable to re-engage in the labor market. People who lost income and could not cope with debts.

Job losses, deterioration of family economies. Difficulty buying medicines.

Drug copayment caused treatments to be left. The food became survival in many families. Other people stopped having leisure activities. They survived.

Cutbacks in PHC do not really affect the population. It was supplied with the enormous professionalism of nursing.

Anxiety, stres.

Labor market volatility has expelled or worsened the working conditions of many people, generating physical, psychological and emotional health problems. Life projects, on many occasions, have been interrupted.

Lack of medication for not being able to pay for it - avoid carrying out necessary tests.

Depriving more vulnerable groups of healthcare. Less investment in health promotion and disease prevention

Food, treatments, housing.

Increased unemployment, increased suicides, mental and emotional disturbances, anxiety depression, etc. Loads of childcare by grandparents, worsening food quality...

Reduction of the purchasing power of families: child poverty, pensioners with family charges, increase of emotional disorders in relation to unfavorable vital situations due to the economic crisis ...

Worse feeding. Unemployment that results in stress and economic situations.

Waiting lists, more demand for urgent visits.

People who welcomed their children and families at home and all lived with the money of one of them.

Poverty, labor exploitation of women, economic overload of the grandparents who end up supporting their families, not being able to buy medication, not being able to make a balanced diet, hopelessness, depression, neglect, dependents, etc. more poor families and when we say of poor families it means of families that did not have access to basic needs. Basic needs such as food, as heating, as light. (VC 2)

The health problems that can be associated with the crisis I think are directly associated with the economic deficit of families. The fact that two families lived with the income of one caused them to lower their guard regarding health surveillance and prevention, had to live day to day. (A 2)

Regarding the Basque Country (Euskadi, in euskera, the local language), the report shows differences in the impact of the crisis, considering that it was smaller than in other communities:

Here in Euskadi there was no real estate bubble that was in the entire Mediterranean, and that there was in much of the world. Here it did occur, the 2008 crisis came with a certain delay, and had an impact on the industry that made part of the working population migrate to other parts of Europe. However, many of these workers some have returned. And it did not have the weight that the crisis had elsewhere. (BC 1)

Some specific rules that were modified or suppressed due to the austerity measures were highlighted, such as the Dependency Law and the issue of subsidy (co-payment) for the purchase of medicines:

It also happened that the whole issue of the Dependency Law. What initiallyemerged as a support for dependents, because in theend what happened was that more dependents areemerging but they are not given the answer and then, of course, you were with people who had been fortunate to have the benefit before the crisis and then the one who requested it, then, took like 2 years, 2 years and a half...there were no resources, he was on hold and usually the patient died before the benefit arrived. That also generated an action on the part of the family and on the part of the patient who did not see that around him there were people who even being better than him as they had been lucky enough to enjoy it, because before they had dependency services and they in worse situation. (A 1)

Nurses and staff engagement and commitment in a PHC project, originated in the previous health reform, stand out, along with feelings of loss and setback, and care model changes when the crisis set in:

We started in 85 and, well, we were coming... we were that health for everyone in the year 2000, Alma Ata... [laughs] we were going to solve everything in $\mathrm{PHC}$...then, when we nurses started, we were inside the doctors' appointments, seeing the prescriptions....and others then it was like the PHC revolution, right? We have autonomy, to see our patients, programs, you know, everything. So, yes, we thought that, of course, as promised, that he developed, it was going to be tremendous! (VC 3)

The working conditions were accumulation of tasks that were assumed, since at that time there was enthusiasm to give Primary Care the value it has, and that at that time it was little considered and that it is today the main point of support of the 2nd and 3rd level and that in those years 
they tried to achieve maximum performance [...] Many health problems were solved by the cohesion of the PHC teams. (A 2)

A professional who has always believed, that is what PHC is, which is being close to the patient and being able to try to promote health and prevent if a disease is already installed ... they saw that it was going losing, losing consciousness, that you could not devote so much time to this nurse activity was easier to assist. In fact, in some health centers that is more important, care. (VC 4)

There is convergence in the answers regarding the assumption that Spain is still experiencing a crisis situation, even though it is alleviated. The main element highlighted to support this assertion is that there has not yet been an effective recovery in investments comparable to pre-crisis levels.

\section{DISCUSSION}

The health consequences of the crisis in Spain are part of a complex process of interaction between social, political, economic and cultural factors, which also have international geopolitical references. In the European Union, macro political decisions should be considered to have been influenced by the European Community institutions. There were special effects in countries such as Spain, Portugal and Greece(8), and consequences on social pacts around welfare policies ${ }^{(13)}$. Troika is an expression that refers to a type of decision-making triumvirate composed of the European Commission, the European Central Bank and the International Monetary Fund. It has led to the imposition of cutbacks on social work, education and health policies through so-called austerity measures. However, it is notorious and public that the bailout of private financial institutions was done through mega packs using public money, which was widely reported by Western media.

The crisis, for Spanish nurses, had different repercussions, depending on how the Autonomous Communities managed health resources. Although there are no national data, in CataIonia, for example, nurses have identified as important negative aspects salary reduction, increased pressure and precariousness at work ${ }^{(14)}$. In terms of staffing, the crisis affected the Specialized Care sector more than the Primary Care sector, although in terms of overall spending, PHC was more affected. The professionals most affected by this decrease in the workforce were nurses ${ }^{(9)}$. Such measures, however, are not equally distributed among the Autonomous Communities. The same study points out that in the Basque Country there was an increase in the number of health professionals in the same period analyzed, as well as in the number of hospital beds, pointing to the continuity of investments in health. Basque nurses also pointed to the occurrence of work overload, especially in $\mathrm{PHC}$, which may be related to the prevalent illness profile and the predominance of the biomedical approach.

The effects of austerity measures, which resulted in cutbacks and resource constraints for the health sector, also resulted in unequal consequences for the population. Although the whole population is thought to have suffered, to a greater or lesser extent, the effects of the crisis, it has more severely affected population groups already penalized by rising unemployment rates. Construction workers or some industries, those already coming from historical trajectories of exclusion and exploitation, such as migrants and gypsies, or the elderly, dependent on social assistance, among them, women were included ${ }^{(15-17)}$.

Among the situations mentioned by the interviewees and in the survey, there is the exclusion of access to the health system by immigrants without a residence permit and the inclusion of co-payments in medicines for the elderly, after the Royal DecreeLaw (RDL) 16/2012 publication. Health professionals in Madrid considered that these measures were not adequately explained in relation to their objectives, and stated that they were guided by the idea of "saving at all costs"(17). Migrants' access to the health system was reestablished by government measure in 2018, but previous restrictive effects are still perceived by nurses.

Regarding the perceived health problems in the population served, some surveys identified that during the initial phase of the crisis, between 2008 and 2012, there was an increase of problems in areas (diagnosis of mental disorders, child health-related quality of life and men's mental health) ${ }^{(6)}$. In Castilla-la-Mancha, there were correlations between increased standardized suicide rates in 2007 and 2008, and Unemployment Rate (positive correlation) and Gross Domestic Product - GDP (negative correlation), compared with the rates in pre-crisis period ${ }^{(18)}$.

The theme of chronic diseases, which represents an important share of health costs and impacts on the population in Spain, was considered by nurses in light of the financial constraints imposed by the crisis. The group most affected by problems related to chronic conditions were the most economically penalized. The theme of education and support for healthy eating and lifestyle is central to nursing care for this group ${ }^{(19)}$. The is less important in a situation where unemployment and helplessness lead to options such as that mentioned by VC 2 . Older people, who have a minimal but insufficient income, support the whole family. They tend to make sacrifices in favor of children, both by decreasing the number of meals and opting for lower cost foods, which are also those that tend to be considered the least healthy.

The set of changes points to an important change in the work process of Spanish community nurse, with difficulties and barriers to fulfill care tasks of individual care due to community work. These difficulties result in tensions between the guiding principles of Spanish community nursing and the many pressures and restrictions suffered by nurses.

Some nurses pointed out that, in the context of the crisis they are experiencing, there is a turn towards a health conception of biomedical and hospital-centric characteristics. This, in turn, is consistent with neoliberal economic and political approaches to social and welfare public policies, the foundations of which have been eroding after the crisis, including in Brazil. Overcoming this dilemma, from the perspective of Spanish community nursing, will only be based on the interrelation of organizational, administrative, training and ethical-political stances. This interrelation should defend the centrality of the person, family and community for integrated, comprehensive and integrative nursing care ${ }^{(20)}$. It is necessary to consider the inseparability between the world of work, where care practices are produced and the world of vocational training. It should be understood beyond the technical and assistance dimension of nursing work, recognizing its role as a social practice that contributes to health as a right ${ }^{(21)}$. 


\section{Study limitations}

The use of a data collection method based on a self-administered questionnaire, disseminated and answered on the internet, makes it difficult to validate qualitative narrative information, and demanded the exclusion of some answers, due to the lack of clarity of the registered text. The number of respondents can also be considered a limit, although information recurrence is a factor to be considered.

It was not possible to access specific technical texts that presented the nature and exact volume of budget and financial cuts that occurred as a result of austerity measures, relying only on information from published articles and reports to discuss this aspect.

\section{Contributions to nursing and public health}

Impacts of political and economic crises on health and health care systems is relevant for nursing at an international level, and allows identifying strategies and care production models that can be shared, strengthening the profession in its common ethical-political bases all over the world. In addition, increases the recognizing of nursing value as a global social practice that defends life and universal access to health, beyond its technical dimension. In this regard, contributions include the areas of assistance, care management and professional training.

Given the cyclical nature of the crises within capitalist accumulation mode, studies in comparative perspective allow to deepen and expand knowledge about threats and potentialities of these crises for universal health systems, updating, at the same time, the discussion of relevant issues for public health at international level.

\section{FINAL CONSIDERATIONS}

In addition to the consequences on health and loss of quality of life of the population, the impacts of the economic crisis affect health care models and the professional autonomy of health professionals, especially nurses. They also impact how much they determine changes and pressure on work processes from interests that disregard professional skills and health realities.

Despite the large impact on overall populations, the increased focus on vulnerable populations indicates liberal policies intensification and their expression in health. Focus indicates that health crises will affect populations differently, helping to widen niches of social inequality. However, work process tends to focus on meeting individual demands. It does not succeed in advancing an approach to the broader processes of health determination, compromising comprehensive, integrated and integrative nursing care among these groups.

The Spanish nurses interviewed indicate that they have some critical insight into the impacts of the crisis and their social role. However, they do not clearly point out the expression of the crisis about their practices and collective work process. Nevertheless, it is considered essential to reflect on the role of nurses as a collective worker and producer of answers and proposals for PHC. Nurses can contribute to coping with crisis situations, precariousness and deconstruction of work processes and threats to the right to health policies.

\section{FUNDING}

This paper was carried out with the support of the Higher Education Personnel Support Coordination (CAPES - Coordenação de Apoio de Pessoal de Nível Superior), funding source 001.

\section{REFERENCES}

1. Campos GWS. Prefácio. In: Mendonça MHM, Matta GC, Gondim R, Giovanella L. Atenção Primária à Saúde no Brasil: conceitos, práticas e pesquisa. 2018. Editora FIOCRUZ, Rio de Janeiro p.15-17.

2. Giovanella L, Stegmüller K. The financial crisis and health care systems in Europe: universal care under threat? Trends in health sector reforms in Germany, the United Kingdom, and Spain. Cad. Saúde Pública. 2014;30(11):2263-81. doi: 10.1590/0102-311X00021314

3. Kemppainen V, Tossavainen K, Turunen H. Nurses' roles in health promotion practice: an integrative review. Health Promot Int. 2012;28(4):490 501. doi : 10.1093/heapro/das034

4. David HMSL, Acioli S, Seidl HM, Brandão OS. O enfermeiro na Atenção Básica: processo de trabalho, práticas de saúde e desafios contemporâneos. In: Mendonça MHM, Matta GC, Gondim R, Giovanella L. Atenção Primária à Saúde no Brasil: conceitos, práticas e pesquisa. 2018. Editora FIOCRUZ, Rio de Janeiro p.337-68.

5. García Armesto, S, Abadía Taira, MB, Durán, A, Hernández Quevedo C, Bernal Delgado, E. España: Análisis Del Sistema Sanitario 2010: resumen e conclusiones. Observatorio Europeo de Políticas y Sistemas de Salud/Sistemas Sanitários In Transición[Internet]. 2011 [cited 2019 Mar 27];12(4):1269. Available from: https://www.mscbs.gob.es/organizacion/sns/planCalidadSNS/pdf/equidad/observatorioEuropeo/InformeHiT2010_ESP.pdf

6. Cagnin RF. O ciclo dos imóveis e o crescimento econômico nos Estados Unidos 2002-2008. Estud Av. 2009;23(66):147-168. doi: 10.1590/ S0103-40142009000200012

7. Bacigalupe A, Escolar-Pujolar A. The impact of economic crises on social inequalities in health: what do we know so far? Int J Equity Health 2014;25:13-52. doi: 10.1186/1475-9276-13-52

8. Guillén Rodríguez AM, González Begega S, Luque Balbona D. Austeridad y ajustes sociales en el Sur de Europa. La fragmentación del modelo de bienestar mediterráneo. Rev Española Sociol[Internet]. 2016[cited 2019 Mar 27];25(2):261-72. Available at: https://recyt.fecyt.es/ index.php/res/article/view/65541/39809 
9. Bandres E, Gonzalez R. La reducción del gasto sanitario en España durante la crisis. Cuad Informac Económ. [Internet]. 2015[cited 2019 Mar 27];248:37-48. Available from: https://www.funcas.es/Publicaciones/Detalle.aspx?ldArt=21986

10. Silva GS, Barbosa ICL, Azevedo EA, Pinheiro HCM. Fundo público e a usurpação dos direitos do trabalho na atualidade. Rev Pol Públic. 2017;21(2):623-40. doi: 10.18764/2178-2865.v21n2p623-640

11. Frigotto G. Trabalho (verbete). In: Pereira IB, Lima JCF. (Orgs.). Dicionário da educação profissional em saúde [Internet]. 2. ed. rev. ampl. Rio de Janeiro: EPSJV. 2009[cited 2019 Mar 27]. p. 399-404. Available from: http://www.sites.epsjv.fiocruz.br/dicionario/verbetes/tra.html

12. Oliveira DC. Análise de conteúdo temático-categorial: uma proposta de sistematização. Rev Enferm UERJ. [Internet]. 2008[cited 2019 Mar 27];16(4):569-76. Available from: http://www.facenf.uerj.br/v16n4/v16n4a19.pdf

13. Begega SG, Balbona DL. González Begega, S. y D. Luque Balbona. Crisis económica y deterioro de los pactos sociales en el sur de Europa: los casos de España y Portuga. Rev Int Sociol. 2015;72(2). doi: 10.3989/ris.2014.03.17

14. Granero A, Blanch, Roldán J, Torralbas J, Escayola A. Crisis en el sector sanitario: impacto percibido en las condiciones de trabajo de las enfermeras. Enferm Clín[Internet]. 2017[cited 2019 Mar 27];27(3):163-71. Available from: http://www.elsevier.es/ es-revista-enfermeria-clinica-35-articulo-crisis-el-sector-sanitarioimpacto-S1130862117300360

15. García González S. El impacto del RDL 16/2012 en la población migrante irregular. Exclusión sanitaria y producción masiva de vulnerabilidad en España. Rev Int Éticas Aplic [Internet]. 2018[cited 2019 Mar 25]: (26):179-87. Availabe from: https://www.dilemata.net/revista/index.php/ dilemata/article/view/412000186

16. Moreno-Colom S, López-Roldán P. El impacto de la crisis en las trayectorias laborales de las mujeres inmigrantes en España. Cuad Relac Labor [Internet]. 2018[cited 2019 Mar 25];36(1):65-87. Availabe from: http://revistas.ucm. es/index.php/CRLA/article/view/59557

17. Heras-Mosteiro J, Otero-García L, Sanz-Barber B, Aranaz-Andrés JM. Percepciones de médicas y médicos de atención primaria de Madrid sobre las medidas de ajuste en el sistema público de salud. Gac Sanit. 2016;30(3):184-90. doi: 10.1016/j.gaceta.2016.02.003

18. Celada JF, Fernández AQ, Moriano AM, Vera IA, Pérez CF, Martín Conty JL. Evolución de la tentativa suicida atendida por los Servicios de Emergencias Médicas de Castilla-La Mancha tras la crisis económica. Rev Soc Esp Med Urg Emerg [Internet]. 2018 [cited 2019 Mar 25];30(4):247-52. Availabe from: http://emergencias.portalsemes.org/descargar/ evolucin-de-la-tentativa-suicida-atendida-por-los-servicios-de-emergencias-mdicas-de-castillala-mancha-tras-la-crisis-econmica/

19. Becker RM, Heidemann ITSB, Meirelles BHS, Costa MFBNA, Antonini FO, Durand MK. Nursing care practices for people with Chronic Noncommunicable Diseases. Rev Bras Enferm[Internet]. 2018 [cited 2019 Mar 22];71(Suppl 6):2643-9. Available from: http://dx.doi. org/10.1590/0034-7167-2017-0799

20. Araújo JL, Freitas RJM, Guedes MVC, Freitas MC, Monteiro ARM, Silva LMS. Brazilian Unified Health System and democracy: nursing in the context of crisis. Rev Bras Enferm. 2018;71(4):2066-71. doi: 10.1590/0034-7167-2017-0352

21. Souza KMJ, Seixas CT, David HMSL, Costa AQ. Contribuições da Saúde Coletiva para o trabalho de enfermeiros. Rev Bras Enferm. 2017;70(3):543-9. doi: 10.1590/0034-7167-2016-0401 